report a low incidence of false-positive studies with thallium-201 imaging.

The cost of the investigation (about $£ 45$ for the isotope alone) probably precludes its use in the regular review of asymptomatic subjects. When, however, a pilot presents with atypical chest pain or an asymptomatic pilot has an equivocal ECG the demonstration of normal stress thallium-201 myocardial images may obviate the need for unnecessary coronary arteriography with its attendant risk.

JAMES H MCKILLOP

R GORDON MURRAY JOHN G TURNER

University Departments of Medicine

and Medical Cardiology,

Royal Infirmary,

Glasgow

' Taradashi, M, et al, Circulation, 1976, 53, suppl 2, p 217

2 Bailey, I, et al, Circulation, 1977, 55, 79

${ }^{3}$ Lenaers, A, et al, fournal of Nuclear Medicine, 1977, $18,509$.

Ritchie, J L, et al, Circulation, 1977, 56, 66.

Rosen

A, et al, American Heart fournal, 1977, 94,

McKillop, J H, et al, Radioactive Isotope in Klinik und Forschung, 1978, 13, 257.

Wainwright, $\mathrm{R}$, et al. Presented to the British Cardiac Society, November, 1977.

\section{Surgery for intermittent claudication}

SIR,-Mr T F Ford and his colleagues (6 May, $p$ 1189) introduce their short report on venesection for patients with intermittent claudication by saying of reconstructive surgery that "the results are not satisfactory." This is a misleading oversimplification. It is perfectly true, as the authors indicate, that reconstructive surgery is not appropriate for the majority of patients with this condition as distinct from the later complications of obliterative arterial disease-rest pain and ulcer-gangrene. It is also true that femoropopliteal bypass has fallen out of favour for claudication because the five-year patency rates are of the order of $40-60 \%$. The patient is likely to outlive his graft and be faced with a more severe ischaemic problem without any saphenous vein being available.

This is not the case when the cause of the claudication lies in the aortoiliac segment. Aortoiliac or aortofemoral reconstruction carries $70-90^{\circ}$, five-year patency and further reconstruction is not pre-empted. The relief of symptoms can therefore be dramatic and sustained provided that patients are selected with care. It would be a pity if $\mathrm{Mr}$ Ford's pessimistic view should discourage the referral of patients with claudication for specialist assessment.

\section{V RUCKLEY}

Western General Hospital, Edinburgh

\section{Umbilical cord prolapse}

SIR,-With reference to your leading article (11 March, p 601) on prolapse of the umbilical cord a number of methods have been suggested to prevent compression of the cord by the presenting part such as the Trendelenburg, knee-chest, and elevated Sims's position. A further manoeuvre is to maintain the fetal head above the pelvic brim by placing two fingers within the vagina. This last method is effective but unpleasant for the mother and wearying for the physician, particularly if the patient has to be transported for some distance.
We have described ${ }^{1}$ a method which has been used successfully in cases of prolapse of the umbilical cord in which vaginal delivery was not imminent. The method is as follows. Immediately on diagnosis of prolapse of the cord, a No 16 Foley catheter with a 5-ml balloon is inserted into the urinary bladder and $500-750 \mathrm{ml}$ of isotonic saline is rapidly introduced by means of an infusion set, after which the balloon is inflated and the cathete clamped. This is done in a moderate Trendelenburg position. The quantity of saline is determined by the appearance of the dispubis. Usually $500 \mathrm{ml}$ is sufficient. The distended bladder maintains the raised position of the presenting part, thus relieving pressure on the cord, without the necessity for the fingers of the assistant to remain in the vagina for a lengthy period. There is the added advantage that when the bladder is distended uterine contractions often diminish or disappear temporarily. At caesarean section the bladder is emptied before opening the parieta peritoneum.

To date we have treated 28 cases of prolapse of the cord by this method with only one neonatal death. The time lapse from diagnosis of the prolapse to delivery varied from 25 to $115 \mathrm{~min}$. The method relieves pressure on the cord and can be safely maintained over a long period of time with little discomfort to the mother and no strain on the attending physician.

Department of Obstetrics and

T VAGO

\section{Gynecology, \\ Barzilai Medical Centre,}

Ashkelon, Israe 1 Vago, T, American fournal of Obstetrics and Gynecology,
1970, 107, 967.

\section{Cough mixtures}

SIR,-In her article (29 April, p 1123) Dr Anne $E$ Tattersfield advocates the use of "either linctus simplex or a linctus containing antihistamines such as diphenhydramine (Benylin) linctus or pseudoephedrine and triprolidine (Actifed) compound linctus" in alleviating cough.

One sees patient after patient who has had bottle after bottle of Benylin and/or Actifed without the slightest effect. The Department of Health and Social Security ${ }^{1}$ reports 17 million prescriptions annually for cough mixtures, the cost of which must be in the region of $f 10-11 \mathrm{~m}$. Surely the time has come when this useless expensive treatmen should be discontinued; certainly it is not to be encouraged.

D ADLER

Ilford, Essex 1 Department of Health and Social Security, Health
and Personal Services 1976. London, HMSO, 1977. tended bladder as a visible swelling above the

\section{A British "Doctors' Ten"}

SIR,-I was interested to read the letters from Dr I D Adams and Dr Barbara Covell (20 May, pp 1352-3) referring to the promotion of running events for interested members of the medical profession in view of the increasing awareness of the value of exercise in the promotion of physical health.

Having no particular enthusiasm for running, I wonder whether a similar event for cyclists would receive worthwhile support. This could be in the form of a group ride over a specified distance to be covered within certain time limits or a specific individual time trial over an accurately measured distance. If there are sufficient doctors interested in taking part in an event of either nature I would be prepared to organise one.

Would anyone interested please write to me, stating their preferences.

R C Goodfellow Senior Medical Officer,
Bitish Nuclear Fuels Ltd.

Springfields Works, Salwick,

Preston, Lancs PR4 0XJ

\section{Shortage specialties}

SIR,-The recruitment to geriatric medicine has been regarded as one of the problem areas of hospital staffing and has been of concern to the Department of Health and Social Security and to regional health boards. Some areas have assumed that the report of the Royal College of Physicians suggesting the creation of posts for physicians "with an interest" would solve the problem and wish to proceed to appointment. Examination of the 1976 figures of staffing of specialties in England and Wales suggests that an alternative course of action may be more appropriate.

The table below shows numbers of consultants and senior registrars (with whole-time equivalents) and honorary (university) posts in four specialties in September 1976. In comparing geriatric medicine with paediatrics and general medicine as examples of established specialties, it is readily seen that the deficit is greatest in the number of university posts. In this respect radiology, another rapidly expanding specialty with serious recruitment problems, shows an even more striking deficit in the same area, even though the numbers of consultants and senior registrars are much higher than in geriatrics and exceed those in paediatrics.

It would appear that in the established and well-staffed specialties there is a large university contribution of one honorary post for every five consultants (WTE) which is lacking in geriatrics $(1: 26)$ and radiology (1:53). In the senior registrar grade the differences are even more marked. Perhaps it would be pertinent to consider at this point whether the "shortage specialties" are unattractive to "good candidates" or whether "good candi-

Numbers of consultants and senior registrars (with whole-time equivalents) and honorary (university) posts, September 1976

\begin{tabular}{|c|c|c|c|c|c|c|}
\hline \multirow{2}{*}{ Specialty } & \multicolumn{3}{|c|}{ Consultant grade } & \multicolumn{3}{|c|}{ Senior registrar grade } \\
\hline & Consultants & $\begin{array}{l}\text { Whole-time } \\
\text { equivalents }\end{array}$ & $\begin{array}{c}\text { Honorary } \\
\text { posts }\end{array}$ & $\begin{array}{l}\text { Senior } \\
\text { registrars }\end{array}$ & $\begin{array}{l}\text { Whole-time } \\
\text { equivalents }\end{array}$ & $\begin{array}{l}\text { Honorary } \\
\text { posts }\end{array}$ \\
\hline $\begin{array}{l}\text { General } \\
\text { medicine } \\
\text { Paediatrics } \\
\text { Geriatrics } \\
\text { Radiology }\end{array}$ & $\begin{array}{r}1048 \\
407 \\
317 \\
736\end{array}$ & $\begin{array}{l}888 \\
359 \\
307 \\
689\end{array}$ & $\begin{array}{r}177 \\
70 \\
12 \\
13\end{array}$ & $\begin{array}{r}203 \\
103 \\
57 \\
169\end{array}$ & $\begin{array}{r}169 \\
88 \\
54 \\
164\end{array}$ & $\begin{array}{r}73 \\
18 \\
3 \\
1\end{array}$ \\
\hline
\end{tabular}


dates" are attracted to specialties with a high honorary:NHS ratio. If the latter is the case, then creating posts for "physicians with an interest" is unlikely to resolve the problem. The creation of additional university departments would not only bring the interest of well-qualified candidates but would greatly assist the existing geriatric units in the task of educating students, doctors, and nurses which is fundamental to improving management of elderly patients in all spheres of clinical practice. It is by no means certain that the development of posts for "physicians with an interest" will bring either the required calibre of candidate or help achieve the necessary expansion of the educational role of geriatric medicine.

JOHN L C DALL

Chairman, Specialty Advisor

Victoria Geriatric Unit, Committee (Geriatrics)

Glasgow

\section{BMA and the Abortion Act}

SIR,-In objecting to the Council's reaffirmation of support for the Abortion Act $\mathrm{Dr} \mathrm{J} \mathrm{H}$ Scotson (13 May, p 1284) asks, I fear rhetorically, "Why should medical ethics be dictated by Parliament ?" I should like to answer this question.

It is because the question of the legal status of abortion is not in fact a matter of medical ethics. It is not a matter of professional standards or of the physician's private relationship with his patient-these are, with the sole exception of emergency treatment, unaffected by either the 1967 Act or any more recent reform proposals.

No, the question of the "civil rights of fetuses" is one for the whole community; and it is one upon which the community is clearly divided. Although repeated opinion polls have shown solid public support for a liberal abortion law and even abortion on request, there remains a minority to whom abortion is repugnant. In a democracy the appropriate way to deal with this problem must be to make it a matter of the individual consciences of women and their medical advisers. It is for Parliament to express this democratic result by legislating to remove abortion from the criminal law.

Abortion Law Reform Association

DAVID FLINT

\section{New consultant contract}

SIR,-Last night I attended a meeting organised by the Central Committee for Hospital Medical Services to explain the proposed new consultant contract. It was presented, very persuasively, as a package with features which some consultants might not like but which should be accepted because of the overriding advantage that it would bring a large increase in income.

The whole case appears to rest on the assumption that the Review Body will price the basic $8+2$ notional half-days (NHDs) at around our present salary so that all further NHDs, together with payments for on-call and teaching, etc, will be extra money. This seems to me highly unrealistic and I was unable to get a satisfactory answer on how this could be equated with the option to stay on the old contract. Unless this option is quite bogus the Review Body will need to ensure that there is reasonable parity between a consultant's salary if he stops on his old contract and what he would receive if his work load was translated to new-contract terms.

As the profession has for years, and quite properly, presented evidence on the hours actually being worked, the Review Body is well aware that most of us will need several extra NHDs to cope with this work load. Therefore either the basic 10 sessions will be priced quite low or the present contract will have to be repriced upwards very considerably. In the latter case the Review Body would presumably also have to give a further rise to general practitioners to maintain the relativity they have been recommended in the most recent report.

Desirable as all this may be I cannot see that even if these recommendations were made the Department of Health and Social Security would accept them. I am afraid that if we accept this new contract in the expectation of being a great deal better off we will not only be disappointed in that respect but will be lumbered with its undesirable features for the rest of our careers.

P W FISHER

Great Bourton,
Nr Banbury, Oxo

SIR,-Most consultants and senior registrars will have read the new contract offer from the Secretary of State; and despite the many documents, letters, and meetings arranged specially to discuss this matter many will still be wondering what it's all about, even though they may well have voted for or against pricing of this contract. What it is all about, of course, is money. The offer from the Secretary of State still has to be priced before any real assessment can be made as to its worth. However, it is not too difficult to see how some things would develop under this new form of contract, regardless of the final pricing.

The contract is supposed to be "workrelated." This is not strictly true, since all the documents refer to time. We all know that time and work are not necessarily the same thing, and those exceptional individuals who hapen to work quickly and expertly will have to slow down or be penalised financially. In many instances the end result is likely to be less work done in a longer time.

The Negotiating Committee are "hopeful" that the basic 10-session contract will be equated to the present full-time salary (that is, some $£ 1200$ per session per annum). If one reads the document carefully it is clear that this is just not on. An individual working all the normal working hours from Monday to Friday will, if he continues with the same work pattern, be paid for 12 sessions. Does this mean a $20^{\circ}$ o rise in salary for no extra work? Also, if we consider two such individuals, one who remains on his present contract (same salary) and the other taking up the new contract (pay for 12 sessions) are we to assume that there will be a $20^{\circ}{ }_{0}$ difference in salary? No Sir, never would any government accept such a situation. The answer, it seems, is that 12 sessions (or more) will become the normal contract to attract the present full-time salary.

Some consultants appear to assume that if they are at present working a "full-time" contract-that is, 11 sessions-then under the new contract they would be paid for an extra two sessions-a total of 13 sessions or (?) a $30^{\circ} \circ$ rise. For some this may well be true, but in the vast majority of cases some of the present 11 sessions will be accounted for by night and weekend working. Under the new contract this will be remunerated separately. Thus if an individual commits two sessions for night and weekend work his normal day-time work will consist of no more than nine sessions. With the two extra sessions allowed for basic on-call and administration his basic contract will be for 11 sessions. Now if 12 sessions is considered necessary for the full present salary this individual will take a cut in basic salary, and will only make up by doing some of the other remunerative work. This is hardly what the Negotiating Committee would have us believe. They insist that an adequate salary should be possible from a basic 10-session contract.

There seems little point in going on and considering further aspects of this present document on the new contract until we have at least some idea of the value the Government is prepared to place on each item. Surely it would have been preferable for the profession to know the score before being committed to a vote. I wonder perhaps if this is the reason why the offer is made at this moment, immediately following a major report from the Review Body.

G JoHNS

W'hitley Bay,

Tyne and Wear

${ }_{*}^{*}$ The Secretary writes: "The issue of pricing the new contract has still to be clarified, and it is to allow it to be clarified that consultants and senior registrars are being asked to support the contract proposals in the ballot. The CCHMS has stated on more than one occasion that disadvantageous pricing would result in rejection of the contract."-ED, $B M Y$.

SIR,-We must all be deeply grateful to $\mathrm{Mr}$

J S S Stewart for his letter (20 May, p 1353).

This unfortunate country is sliding headlong into communism via the closed shop and interference with our affairs. The new "contract" will restrict, tightly, consultants" activities: the suggested flexibility exists only in our minds, certainly not in the minds of our masters. The contract is within a hair's breadth of imposing "clocking in and out" to prove that work has been done. The risk of our activities out of working hours being "monitored" is only just not written in but will be an inevitable accompaniment of the arrangements. No trade union would stand for such a thing.

With few exceptions consultants need better working conditions and less administrative demands to detract from our work. We need money only to compensate for the losses accruing from Government mismanagement. We certainly do not need a new set of chains. We need more freedom and proper reward for our labour. Unless more money is voted, put into writing beyond revocation, the new contract is only uninteresting verbiage-and dangerous at that.

A E CARTER

London W5

***The Secretary writes: "The new contract involves no change in the notional half-day, which will continue to be worked flexibly. There is no question of "clocking in and out" as suggested by $\mathrm{Mr}$ Carter."-ED, BMF. 